УДК 78.422

DOI https://doi.org/10.24919/2308-4863/34-1-7

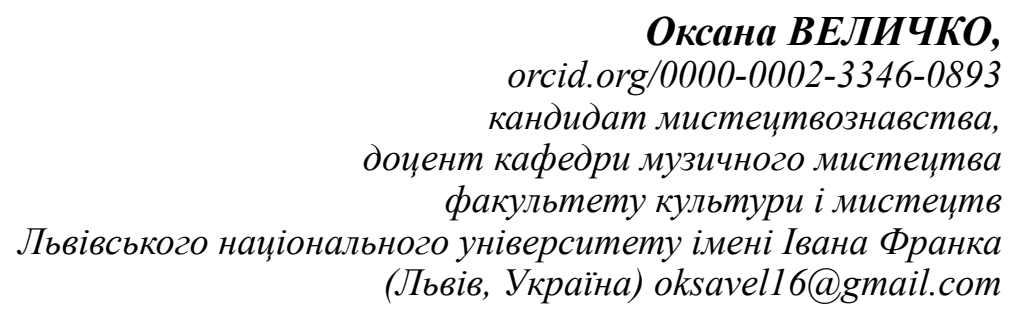

Ірина МАКОВЕЦЬКА, orcid.org/0000-0002-5046-6242 заслужена артистка України, асистент кафедри музичного мистечтвва факультету культури і мистеитв Львівського національного університету імені Івана Франка (Львів, Украӥна) makovetskyy.r@gmail.com

\title{
ВИКОНАВСЬКІ ЗАСАДИ ВІДЕНСЬКОЇ ФОРТЕПІАННОЇ ШКОЛИ У ДІЯЛЬНОСТІ ЙОГАННА НЕПОМУКА ГУММЕЛЯ ТА КАРЛА ЧЕРНІ
}

Багатогранна, мультинаціональна музична культура Відня вирізняється барвистою палітрою визначних постатей та їхніх творчих досягнень. У статті розглядаються виконавсько-дидактичні вектори Віденської фортепіанної школи на прикладі діяльності ї̈ провідних репрезентантів. Мета статті - проаналізувати методико-виконавські принципи Й. Н. Гуммеля та К. Черні в контексті Віденської фортепіанної школи. Гармонія почуття та розуму, експресії та майстерності - ось символи виконавства австрійської піаністики класицистично-романтичної доби. У Віденській фортепіанній школі значна увага надавалась традиційним жанровим основам музики, виразному веденню мелодії, збалансованій динаміці й гнучкому виконавському темпоритму. Нові інструменти віденської та англійської механіки сприяли поширенню віртуозного виконавства, яке стало ознакою «блискучого стилю» (Stil brillanto), поширеному у фортепіанному виконавстві першої половини XIX ст. Він передбачав орієнтацію на велику естраду, особливий спосіб орнаментування, варіювання, нові ефектні фактурні прийоми тощчо. Творча діяльність Й. Н. Гуммеля та К. Черні охопила період на зламі епохи Класицизму й появи Романтизму. Означені митиі проводили різносторонню музичну діяльність, здобули визнання як творчі особистості ранньоромантичного періоду, які сформували основи естетики Романтизму. Методичні праиі Й. Н. Гуммеля та К. Черні відіграли важливу роль у фортепіанній педагогіиі, на них базувалась виконавська й педагогічна практика наступних генерацій. Можемо констатувати, щчо їхні методичні поради, систематизовані в Школах гри, й донині не втратили актуальності, вони дали колосальний поштовх до фахового навчання гри на фортепіано. Ці музиканти вивчали розвиток і впровадження інструменту фортепіано в тогочасний культурний простір, досліджували парадигму естетики фортепіанного виконавства, на якій базувалася музика епохи Романтизму.

Ключові слова: віденська фортепіанна школа, педагогіка, виконавець-віртуоз, стиль, романтизм. 


\section{Oksana VELYCHKO, orcid.org/0000-0002-3346-0893 \\ PhD (Art Sciences), \\ Associate Professor at the Department of Musical Art \\ of the Faculty of Culture and Arts \\ Ivan Franko National University of Lviv \\ (Lviv,Ukraine) oksavel16@gmail.com}

Iryna MAKOVETSKA, orcid.org/0000-0002-5046-6242

Honored Artist of Ukraine,

Senior Lecturer at the Department of Musical Art

of the Faculty of Culture and Arts

Ivan Franko National University of Lviv

(Lviv, Ukraine) makovetskyy.r@gmail.com

\section{PERFORMANCE FUNDAMENTALS OF THE VIENNA PIANO SCHOOL IN THE ACTIVITY OF JOHANN NEPOMUK HUMMEL AND CARL CZERNY}

The multifaceted, multinational musical culture of Vienna is distinguished by a colourful palette of prominent figures and creative achievements. The article considers the performance and didactic vectors of the Vienna Piano School on the example of the activities of its leading representatives. The purpose of the article is to analyze the methodological and performing principles of J. N. Hummel and C. Czerny in the context of the Vienna Piano School. The harmony of feelings and reason, expression and skill - these are the symbols of the Austrian piano school of the classic-romantic era. The Vienna Piano School paid considerable attention to the traditional genre foundations of music, expressive melody, balanced dynamics and flexible performance tempo-rhythm. New instruments of Viennese and English mechanics contributed to the spread of virtuoso performance, which became a sign of "brilliant style" (Stil brillanto), common in piano performance of the first half of the nineteenth century. It provided for the focus on a large stage, a special way of ornamentation, variation, new impressive textural techniques etc. Creative activity of J. N. Hummel and C. Czerny covered the period at the turn of the Classicism era and the emergence of Romanticism. These artists carried out a variety of musical activities, gained recognition as creative personalities of the early Romantic period, which formed the basis of the aesthetics of Romanticism. Methodical works of J. N. Hummel and C. Czerny played an important role in piano pedagogy, on which the performing and pedagogical practice of the next generations was based. We have concluded that their methodical advices, systematized in the Schools of Playing, haven't lost its relevance to this day. They gave a tremendous impetus to the professional training of the piano. These musicians studied the development and introduction of the piano instrument in the cultural space of the time, studied the paradigm of the aesthetics of piano performance, on which the music of the Romantic era was based.

Key words: Viennese piano school, pedagogy, virtuoso performer, style, romanticism.

Постановка проблеми. У Відні, культурному центрі Австро-Угорської імперії, мистецькі особистості прагнули розкрити творчий потенціал. У царині музичного мистецтва вирізнявся симбіоз творчої взаємодії композиторів, виконавців і музичних критиків. Важливу роль у музичному житті займали піаністи-віртуози й педагоги. Яскравими репрезентантами Віденської фортепіанної школи були відомий австрійський піаніст і композитор Йоганн (Ян) Непомук Гуммель (Johann Nepomuk Hummel) (1778-1837 pp.) та уславлений фортепіанний педагог і композитор чеського походження Карл Черні (Carl Czerny) (1791-1857 рр.).

Аналіз досліджень. Особливості Віденської фортепіанної школи й діяльність іï репрезентантів вивчала когорта зарубіжних та українських дослідників, серед яких Карл Беньовський (Karl
Benyovszky) (Benyovszky, 1934), Матіас Вендт (Matthias Wendt) (Wendt, 2003), Зігфрід Маузер (Siegfied Mauser) (Mauser, 1992), Кароль Була (Karol Bula) (Bula, 1978), Лін Геллер (Lynne Heller), Ніколаус Харнонкурт (Nikolaus Harnoncourt) (Харнонкурт, 2002), О. Алєксєєв (Алєксєєв, 1974), Н. Кашкадамова (Кашкадамова, 2006), О. ДітчукСтанько й інші. Пропонована ж розвідка покликана доповнити наявні знання 3 означеної проблеми, вона уточнює ключові поняття, матеріали й факти щодо діяльності Й. Н. Гуммеля та К. Черні.

Мета статті - проаналізувати методико-виконавські принципи Й. Н. Гуммеля та К. Черні в контексті Віденської фортепіанної школи.

Виклад основного матеріалу. До початку XIX ст. музична освіта була здебільшого приватною. «Музикант навчав учнів свого фаху, < . .> стосунки майстер-учень були обов' язковими у музиці, 
$<\ldots>$ це стосувалося техніки композиції, гри на інструменті, <..> майстер навчав стилістичної інтерпретації» (Харнонкурт, 2002: 15). Паризька консерваторія, заснована в 1795 р., тоді була найстаршим державним спеціальним музичним закладом, охочих навчатися в ній було дуже багато. Її вихованці виступали 3 публічними концертами, які викликали значний культурний резонанс.

У першій половині XIX ст. з'явилося чимало музичних закладів. Відповідно, зросла потреба у кваліфікованих педагогах. У той час низка видатних піаністів-віртуозів розробляла власні методи навчання та на їх основі видавали «Школи гри на фортепіано». Причому це стосувалося саме фортепіанної педагогіки, а не клавірної, яка передбачала уміння композиції, імпровізації та акомпанементу.

Тогочасні видатні педагоги-віртуози - передусім Й. Н. Гуммель, К. Черні, Муціо Клементі (Muzio Clementi) (1752-1832 pp.), Йоганн Баптист Крамер (Johann-Baptist Cramer) (1771-1858 pp.), Фрідріх Калькбреннер (Friedrich Kalkbrenner) (1785-1849 pp.), Ігнац Мошелес (Ignaz Moscheles) (1794-1870 pp.) та інші - заклали основи Віденської фортепіанної школи. До її засад належали розвиток технічної біглості, досягнення сили й рівності звучання, для цього педагоги пропонували розмаїті етюди й вправи (згадаймо етюди «Школи біглості» К. Черні). Фундамент Віденської фортепіанної школи склали численні етюди й вправи. Вершини віртуозності досягались шляхом послідовного опанування технічними навичками, від простіших до складніших. У добу Бароко із цією ж метою Йоганн Себастьян Бах (Johann Sebastian Bach) (1685-1750 pp.) писав інвенції та синфонії, в яких насамперед превалювали композиційні завдання. Натомість у Віденській фортепіанній школі головна увага приділялась розвитку виконавської техніки. Після подолання технічних завдань $\dddot{1}$ вихованці здобували навички гарного звуковидобуття.

Поради К. Черні-педагога залишаються актуальними й у сучасній педагогіці. Слід підкреслити, що К. Черні розмежовував концертне виконання та камерне. Для великої аудиторії, щоб захопити слухача, від виконавця вимагалась певна бравурність і бездоганна технічна майстерність, вільне володіння найвищим ступенем біглості в поєднанні із чіткістю та абсолютно точним виконанням нотного тексту. Водночас ознакою того часу була імпровізаційність виконавця під час виступу.

Важливим компонентом Віденської фортепіанної школи було досягнення спеціального туше perle, точний і виразний пальцевий удар. Головною ознакою віртуозного виконання стало тяжіння до гри «широким мазком». Водночас культивувалося й ажурно-орнаментальне камерне виконання, яке характеризувалось внутрішньою збалансованістю динаміки. До прикладу, відомий німецький композитор і піаніст Людвіг ван Бетховен (Ludwig van Beethoven) (1770-1827 pр.) критикував блискучий піанізм, він вимагав максимально вдумливого ставлення до тексту музичного твору, який, на його переконання, мав виражати загальнофілософські ідеї та глибокий зміст.

У XVIII ст. майстри фортепіано розробили модель, відому під назвою «Віденське фортепіано», iii можливості були ідеально пристосовані до блискучого стилю гри. Інструмент мав легку на дотик клавіатуру, світлий, дзвінкий звук, невелику силу звучання, допускав ефект perle тощо. Якості нового інструменту яскраво увиразнив у клавірній творчості відомий австрійський композитор і виконавець-віртуоз, один із представників Віденської класичної школи Вольфганг Амадей Моцарт (Wolfgang Amadeus Mozart) (1756-1791рр.). Його традицію виконавства продовжив у виконавській і композиторській діяльності Й. Н. Гуммель, який у дитинстві навчався у В. А. Моцарта, згодом в іншого представника «Віденської класичної школи» Йозефа Гайдна (Joseph Haydn) (1732-1809 рр.). Й. Н. Гуммель зробив редакції семи фортепіанних концертів В. А. Моцарта, розшифрував ескізно написані фрагменти, орнаментації повільних частин і повторень, створив власні каденції (Кашкадамова, 2006: 42). Його праця мала неоціненне значення, тому що він як учень В. А. Моцарта зумів передати стиль письма й творчий дух свого педагога.

Паростки «блискучого стилю» (Stil brillant) сформували Ян Ладислав Дусік (Jan Ladislav Dusík) (1760-1812 pp.) і М. Клементі. Означений стиль був притаманний творчості Й. Н. Гуммеля, I. Мошелеса, Ф. Калькбренера, Анрі Герца (Henri Herz) (1803-1888 pp.), Карла Марії фон Вебера (Carl Maria von Weber) (1786-1826 pp.), Фелікса Мендельсона (Felix Mendelssohn) (1809-1847 pр.), Фридерика Шопена (Fryderyk Chopin) (1810-1849 pp.), Ференца Ліста (Ferenc Liszt) (1811-1886 pp.). Як зазначила Н. Кашкадамова, «це не був зовсім самостійний історичний стиль $<\ldots>$ у музичній мові він спирався на засади класицизму: ясність i докладність фактури й виконання, карбовану ритміку, завершеність кожної деталі <...> згодом став передбачати прикмети романтизму» (Кашкадамова, 2006: 11).

Спираючись на поетику В. А. Моцарта, Й. Н. Гуммель пропагував витончену ліричну співучість. Його новації вплинули на фортепіанну 
творчість ранніх романтиків. Виступи Й. Н. Гуммеля-піаніста у Відні як репрезентанта ліричновіртуозної лінії виконавства супроводжувалися сенсаційним успіхом. Багато музикантів виявили бажання навчатися в нього, серед них Роберт Шуман (Robert Schumann) (1810-1856 pp.), який спеціально вирішив перервати навчання у Фрідріха Віка (Friedrich Wieck) (1785-1873 рр.) і продовжити його в Й. Н. Гуммеля. «Він інтенсивно студіював його Сонату fis-moll op. 81 і Концерт для фортепіано a-moll op. 85. Особливий вплив на формування Р. Шумана як піаніста мала методична праця «Школа клавіру» (Klavirschule) Й. Н. Гуммеля, написана в 1828 p.» (Wendt, 2003: 125).

У першій половині XIX ст. отримали поширення публічні виступи, на яких виконувалися концерти, зокрема Даніеля Штайбельта (Daniel Steibelt) (1765-1823 pр.), Й. Б. Крамера, сім концертів Й. Н. Гуммеля, п'ятнадцять концертів Я. Л. Дусіка. Концерти a-moll op. 85 i h-moll op. 89 Й. Н. Гуммеля, позначені оригінальними стилістичними знахідками, ще за життя композитора отримали велику популярність. Їм притаманні як віртуозність, так і лірична співучість, звукозображальні й сонористичні елементи, вони рясно оздоблені мелізмами.

Творчі досягнення Й. Н. Гуммеля дали поштовх розвитку романтичного фортепіанного концерту, стали підгрунтям для появи фортепіанних концертів Ф. Шопена, в яких «блискучий стиль досяг своєї вершини й завершення» (Кашкадамова, 2006: 12). У роботі «Школа клавіру» (Klavirschule) Й. Н. Гуммель проаналізував властивості англійської та віденської механіки фортепіано. Вдосконалення інструменту з віденською механікою корелювало 3 віртуозним стилем виконавства. Інструменту із цією механікою надавали перевагу Й. Н. Гуммель і Ф. Шопен. У фортепіанних творах Й. Н. Гуммеля педаль використовувалась спорадично, тому їм добре годилися нові інструменти 3 віденською механікою. На противагу Й. Н. Гуммелю Л. ван Бетховен використовував фортепіано 3 англійською механікою, яка резонувала драматичному стилю композитора, з об'ємнішим звуком, гучнішими басами, барвистим регістровим забарвленням: «Три останні сонати ор. 109, op. 111, op. 106, Варіації Діабеллі ор. 120 за звуковою виразністю ніби написані спеціально для англійської механіки» (Mauser, 1992: 388).

Слід зазначити, що на концертній сцені конкурентом Й. Н. Гуммеля був Л. ван Бетховен. $\mathrm{У}$ ті часи була поширена змагальність між виконавцями блискучого стилю, до якого належали Й. Єлінек, Й. Вьольфль, І. Мошелес, С. Тальберг,
Й. Н. Гуммель і Л. ван Бетховен, який був апологетом новаторських принципів драматичного протиставлення. Показово, що фортепіанний симфонізм, прихильником якого був Л. ван Бетховен, згодом отримав продовження у творчості Ф. Ліста, а віртуозний блискучий стиль, якого дотримувався Й. Н. Гуммель, розвинувся в піаністичній діяльності Ф. Шопена, який із ранніх романтиків найбільше виділяв Й. Н. Гуммеля, а його творчість називав «ключем до високої фортепіанної гри» (Bula, 1978: 40).

Методичні праці Й. Н. Гуммеля займали чільне місце у виконавській практиці. Зокрема, імпульси для новаторської естетики фортепіанної гри Ф. Шопен черпав із відомої методичної праці Й. Н. Гуммеля «Детальна теоретична й практична інструкція про те, як грати на фортепіано форте, від перших уроків до найповнішого навчання в 1828 році» (Ausführliche theoretisch-praktische Anweisung zum Piano-Forte-Spiel, vom ersten Elementar-Unterrichte an bis zur vollkommensten Ausbildung von 1828) (8). Означена праця Й. Н. Гуммеля складається 3 трьох частин. Перша частина призначалась для початківців. Автор вважав, що спочатку слід зацікавити учня до навчання, лише згодом вимагати зосередженості й слухового контролю. Він застерігав від безконечних механічних тренувань, які могли «зруйнувати зацікавленість учнів до гри» (Hummel, 1928/1989: 426).).

У другій частині методичної праці, присвяченій роботі над аплікатурою, Й. Н. Гуммель навів численні вправи, які становили квінтесенцію фортепіанної техніки першої половини XIX ст., а саме: перенесення позиції, підкладання та перекладання, підміна пальців, розтягнення та стрибки, використання першого й п'ятого пальців на чорних клавішах, чергування пальців під час репетицій, гра одним пальцем, перекладання рук тощо (Hummel, 1928/1989: 428). Вибираючи аплікатуру, він радив керуватись не тільки зручністю, але й відповідністю фактури фрагменту твору - такий підхід був вкрай інноваційним для того часу.

Третя частина праці під назвою «Про виконання» стосувалась проблем інтерпретації. Митець стверджував: «Темп Allegro вимагає глянцу, сили, блиску, рішучості виконання, енергетики біглості пальців, ліричні ж частини мають виконуватись виразно, але водночас в одному темпі й характері, щоб зберігалась цілісність частин» (Hummel, 1928/1989: 428).

На думку Й. Н. Гуммеля, фундаментом для якісного виконання $\epsilon$ «повний контроль над пальцями, які мають бути здатними до будь-якого відтінку звуковидобуття... Однак цього можна досяг- 
нути лише шляхом найтоншого внутрішнього відчуття над пальцями» (Алексеев, 1974: 78). Митець диференціював поняття «правильного» й «гарного виконання», розмірковував співвідношенням у музичному виконавстві раціонального й інтуїтивного первнів. Він вважав, що «правильне» виконання досягається завдяки тренуванням, а «гарне» базується на інтуїтивних відчуттях (Кашкадамова, 2006: 42). Цінним є розділ праці, присвячений мелізмам, у ньому вперше митець запропонував виконувати трель 3 основного тону, це отримало широке застосування в романтичній виконавській практиці. Однією з позицій естетики Й. Н. Гуммеля була вимога «не заливати педаллю ноти» (Hummel, 1928/1989: 428).

Найбільш вдало блискучий стиль проявився в жанрах варіації, рондо й фантазіі, в яких містились також риси імпровізаційності. За життя Й. Н. Гуммель отримав славу майстерного імпровізатора, як правило, його імпровізації укладались у структуру теми 3 кількома варіаціями, які завершувались блискучим рондо або фугою (це було даниною попередній традиції). К. Черні, який був палким прихильником творчості Л. ван Бетховена, в автобіографії в 1842 р. писав: «Якщо в стилі Бетховена є неймовірна сила й бравурна біглість, то стиль Гуммеля відзначається ясністю, чистотою, виразністю, елегантністю та ніжністю, технічна віртуозність розрахована на найвищий ефект здивування, на кшталт стилю Моцарта, який він поєднав 3 віртуозністю М. Клементі» (Benyovszky, 1934: 140).

Новацією естетики К. Черні був підхід до інтерпретації музичних творів у взаємозв'язку зі стильовими особливостями. Зокрема, він виділив шість різних творчих напрямків, які мали відмінні способи виконання (Кашкадамова, 2006: 45). На його думку, М. Клементі володів сильним ударом, чітким виконанням у швидкому темпі й правильною декламацією; І. Крамер та Я. Л. Дусік захоплювали слухачів cantabile, надзвичайною рівністю в пасажах і досконалим legato 3 використанням педалі, вони уникали різких ефектів; В. А. Моцарт презентував ясне, одухотворене виконання, розраховане більшою мірою на staccato, аніж на legato; Л. ван Бетховен надавав перевагу драматичній фактурі, яка контрастувала 3 legato cantabile; гра репрезентантів «блискучої школи» - Й. Н. Гуммеля, Ф. Калькбренера, I. Мошелеса й інших - характеризувалася досконалою біглістю, вишуканими прикрасами, чіткістю звучання, особливою декламацією з тонким смаком; С. Тальберг, Ф. Ліст і Ф. Шопен відзначались використанням нової фактури, звукових ефектів, вони зуміли використати всі переваги вдосконаленого фортепіано 3 віденською та англійською механікою (Кашкадамова, 2006: 45).

Методичні засади К. Черні грунтувалися на успішному педагогічному досвіді. У нього навчались визначні музиканти романтичної доби, серед яких Ф. Ліст, Т. Кулак, Т. Лешетицький, Н. Бельвіль-Урі, Т. Дьолєр і багато інших. Праця К. Черні «Повна теоретично-практична школа фортепіано, 3 початкового рівня до вищого, що складається із численних прикладів, укладених в 4-х частинах» (Vollständige theoretisch-praktische PianoforteSchule von dem ersten Anfange bis zur höchsten Ausbildung fortschreitend und mit allen nötigen, zu diesem Zwecke eigends komponierten, zahlreichen Beispielen in 4 Teilen) (1846 p.) (Czerny, 1846) це систематизоване зібрання його найцінніших методичних вказівок, написане на основі «Школи клавіру» Й. Н. Гуммеля. Крім того, К. Черні відвідував уроки М. Клементі, врахував методичний досвід інших педагогів - Жан Луї Адана (Jean Louis Adan) (1758-1848 pp.) і Сигізмунда Тальберга (Sigismund Thalberg) (1812-1871 pp.).

Об'ємна за обсягом матеріалу означена праця К. Черні виявилась доступною в практичному застосуванні, вона узагальнила досвід викладання гри на фортепіано попередників автора й містить квінтесенцію його власних методичних підходів. Дотримуючись настанов свого вчителя Л. ван Бетховена, К. Черні радив задля досягнення біглості пальців грати гами. Спеціальну увагу він звертав на піаністичний апарат: кисті, зап'ястя, ваги рук залежно від завдань того чи іншого музичного твору. К. Черні радив бути уважним до динамічних відтінків, артикуляції, темпоритму, орнаментики й педалізації. На відміну від Й. Н. Гуммеля, він виступав за виконання музичних творів напам'ять. Окремим розділом його праці було «Мистецтво виконання старих і нових фортепіанних творів», в яких наголошувався зв'язок інтерпретації зі стильовими особливостями виконуваних творів.

Висновки. Термін «Віденська фортепіанна школа» став своєрідним брендом у формуванні явища європейського піанізму. Віденська фортепіанна школа характеризується усталеними, історично сформованими традиціями й високопрофесійними здобутками. У різні часові відтинки тут творило багате гроно видатних піаністів-педагогів, серед яких - Й. Н. Гуммель і К. Черні.

Виконавська творчість Й. Н. Гуммеля перепліталася 3 композиторською, характеризувалася численними піаністичними нововведеннями. У царині техніки митець дотримувався різноманітної артикуляції, трактував legato як основний 
спосіб звуковидобування. Й. Н. Гуммель збагатив піаністичний репертуар новими технічними прийомами, винятковою віртуозністю.

До основних педагогічно-методичних принципів К. Черні належали: розкриття індивідуальності учня, формування його досконалої піаністичної майстерності й всебічний розвиток, планомірний підхід до навчання та виховання дисципліни «думок та емоцій». Особливу увагу він приділяв роботі над пальцевою технікою, яку вважав основою гри, але не самоціллю. Як і Й. Н. Гуммель, К. Черні приділяв значну увагу проблемі інтерпретації, методиці вивчення музичних творів тощо.

У подальших розвідках видається доцільним порівняти Віденську фортепіанну школу з методико-виконавськими засадами інших європейських піаністичних шкіл.

\section{СПИСОК ВИКОРИСТАНИХ ДЖЕРЕЛ}

1. Алексеев А. Из истории фортепианной педагогики : хрестоматия. Киев, 1974. 165 с.

2. Кашкадамова Н. Історія фортепіанного мистецтва XIX ст. Тернопіль, 2006. 606 с.

3. Мильштейн Я. Очерки о Шопене. Москва, 1987. 176 с.

4. Харнонкурт Н. Музика як мова звуків: шлях до нового розуміння музики. Суми : Собор, 2002. 183 с.

5. Benyovszky K. Johann Nepomuk Hummel: Der Mensch und Künstler. Bratislava : Eos-Verlag, 1934. 392 p.

6. Bula K. Über die Bedeutung Johann Nepomuk Hummels kompositorisch-technischen Errungenschaften für die Gestaltung des Klavierstils von F. Chopin. Bericht der wissenschaftlichen Konferenz aus Anlass des 200. Geburtstages Johann Nepomuk Hummels am 18 November 1978 in Weimar / Hans Rudolf Jung, Hg. Weimar, 1978. S. 39-48.

7. Czerny C. Vollständige theoretisch-praktische Pianoforte-Schule von dem ersten Anfange bis zur höchsten Ausbildung fortschreitend und mit allen nötigen, zu diesem Zwecke eigends komponierten, zahlreichen Beispielen in 4 Teilen verfasst von Carl Czerny. Op. 500. Wien : die A. Diabelli u. Comp., 1846.

8. Hummel J. N. „Ausführliche theoretisch-praktische Anweisung zum Piano-Forte-Spiel, vom ersten ElementarUnterrichte an bis zur vollkommensten Ausbildung" von 1828 Reprint - Ausgabe. Wien : Tobias Haslinger, 1928/1989. 482 S.

9. Mauser S. Klavier-und Kammermusik. Hermann Danuser, Hg. Musikalische Interpretation. Neues Handbuch der Musikwissenschaft 11. Laaber: Laaber-Verlag, 1992.

10. Wendt M. Schumann und Hummel. Zwischen Klassik und Klassizismus - Johann Nepomuk Hummel in Wien und Weimar / Gerhard Anselm, Laurenz Luttken, Hg. Kassel, 2003. S. 123-145.

\section{REFERENCES}

1. Alekseev A. Iz istorii fortepiannoj pedagogiki. Khrestomatiya. [From the history of piano pedagogy]. Kiev, 1974, $165 \mathrm{p}$. [in Russian].

2. Kashkadamova N. Istoriia fortepiannoho mystetstva XIX st. [History of piano art of the XIXth century]. Ternopil, 2006, 606 p. [in Ukrainian].

3. Mil'shtejn Ya. Ocherki o Shopene. [Essays about Chopin]. Moskva, 1987, 176 p. [in Russian].

4. Kharnonkurt N. Muzyka yak mova zvukiv: shliakh do novoho rozuminnia muzyky [Music as a language of sounds: a way to a new understanding of music]. Sumy, 2002, 183 p. [in Ukrainian].

5. Benyovszky K. Johann Nepomuk Hummel: Der Mensch und Künstler. [Johann Nepomuk Hummel: Man and Artist]. Bratislava: Eos-Verlag, 1934. [in German].

6. Bula K. Über die Bedeutung Johann Nepomuk Hummels kompositorisch-technischen Errungenschaften für die Gestaltung des Klavierstils von F. Chopin. [About the importance of Johann Nepomuk Hummel's compositional and technical achievements for the design of the piano style of F. Chopin]. Hans Rudolf Jung, Hg. Bericht der wissenschaftlichen Konferenz aus Anlass des 200. Geburtstages Johann Nepomuk Hummels am 18 November 1978 in Weimar. [Report of the scientific conference on the occasion of the 200th birthday of Johann Nepomuk Hummel on November 18, 1978 in Weimar]. Weimar, 1978, S. 39-48. [in German].

7. Czerny C. Vollständige theoretisch-praktische Pianoforte-Schule von dem ersten Anfange bis zur höchsten Ausbildung fortschreitend und mit allen nötigen, zu diesem Zwecke eigends komponierten, zahlreichen Beispielen in 4 Teilen verfasst von Carl Czerny, op. 500 [Complete theoretical and practical pianoforte school from the first beginning to the highest training progressing and with all the necessary numerous examples specially composed for this purpose in 4 parts written by Carl Czerny, op. 500]. Wien: die A. Diabelli u. Comp., 1846. [in German].

8. Hummel J. N. „Ausführliche theoretisch-praktische Anweisung zum Piano-Forte-Spiel, vom ersten Elementar-Unterrichte an bis zur vollkommensten Ausbildung" von 1828 Reprint - Ausgabe. ["Detailed theoretical and practical instructions on how to play the Piano Forte, from the first elementary lessons to the most complete training" from 1828 Reprint edition]. Wien: Tobias Haslinger, 1928/1989. [in German].

9. Mauser S. Klavier-und Kammermusik [Piano and chamber music]. Hermann Danuser, Hg. Musikalische Interpretation. Neues Handbuch der Musikwissenschaft 11 [Musical interpretation. New manual of musicology]. Laaber: Laaber-Verlag, 1992. [in German].

10. Wendt M. Schumann und Hummel [Schumann und Hummel]. Gerhard Anselm, Laurenz Luttken, Hg. Zwischen Klassik und Klassizismus - Johann Nepomuk Hummel in Wien und Weimar. [Between classical and classicism - Johann Nepomuk Hummel in Vienna and Weimar]. Kassel, 2003, S. 123-145. [in German]. 